\title{
Test anxiety among English language learners: A case of vocabulary testing using multiple-choice items and error identification tests
}

\author{
Yasin Khoshhal ${ }^{1}$ \\ Research article. Received: 08/08/2020. Accepted: 13/11/2020. Published in advance: 14/12/2020. Published: 04/01/2020.
}

\begin{abstract}
INTRODUCTION. This study sought to discern the impact of test anxiety on English language learners' test performance.

METHOD. Fifty female learners at intermediate and upper-intermediate levels of English were divided into two groups - Multiple-Choice (MC) and Error Identification (EI) - according to their scores in vocabulary tests given in the pre-treatment phase. A questionnaire was then administered to assess the level of anxiety brought about by these tests. During a 20-week period the El group received lesson plans designed based on error-identification activities, while the MC group was offered instructions including multiple-choice items. After the treatment, the same tests and questionnaire were administered.
\end{abstract}

RESULTS and DISCUSSION. The findings showed that the level of test anxiety was higher in the El group compared with the MC group. The positive role of familiarization and the negative impact of debilitative anxiety were observed through this study. The findings of the current study can be transferred to other high-stake proficiency tests.

Keywords

Assessment; Error identification; Multiple-choice items; Test anxiety; Vocabulary knowledge.

Author information

${ }^{1}$ University of Guilan, Iran. Department of English Language and Literature. Contact: Yasin_kd@msc.guilan.ac.ir

\section{Recommended reference}

Khoshhal, Y. (2021). Test anxiety among English language learners: A case of vocabulary testing using multiple-choice items and error identification tests. REIRE Revista d'Innovació i Recerca en Educació, 14(1), 1-11. https://doi.org/10.1344/reire2021.14.132147

(C) 2021 The author. This is an open access article distributed under the Creative Commons Attribution 4.0 International License, which permits unrestricted use, distribution, and reproduction in any medium, provided the original work is properly cited. To view a copy of this license, visit https://creativecommons.org/licenses/by/4.0/ 
Títol (català)

L'ansietat en els exàmens en els estudiants d'anglès: un cas de proves de vocabulari amb preguntes d'elecció múltiple i proves d'identificació d'errors

\section{Resum}

INTRODUCCIÓ. L'estudi intenta discernir l'impacte que té l'ansietat provocada pels exàmens en el rendiment dels aprenents d'anglès.

MÈTODE. Cinquanta dones estudiants d'anglès dels nivells intermedi i mitjà-superior es van dividir en dos grups —elecció múltiple (EM) i identificació d'errors (IE) - segons les puntuacions que havien obtingut en els exàmens de vocabulari fets en la fase pretest. Després, es va administrar un qüestionari per valorar el nivell d'ansietat que els havien provocat aquests exàmens. Durant un període de vint setmanes, el grup IE va fer activitats basades en la identificació d'errors, mentre que al grup EM se li van oferir classes que incloïen exercicis d’elecció múltiple. Després d'aquesta etapa, es van tornar a aplicar els mateixos exàmens i el qüestionari.

RESULTATS I DISCUSSIÓ. Els resultats van demostrar que el nivell d'ansietat en els exàmens va ser més alt en el grup que va rebre el format d'IE. A través d'aquest estudi es va observar el paper positiu de la familiarització i l'impacte negatiu de l'ansietat debilitativa. Les conclusions d'aquest estudi es poden transferir a altres proves de competència d'alt nivell.

Paraules clau

Avaluació; Identificació d’errors; Preguntes d'elecció múltiple; Ansietat en els exàmens; Coneixement de vocabulari

\section{Título (castellano)}

Ansiedad ante los exámenes en estudiantes de inglés: un caso de pruebas de vocabulario utilizando preguntas de opción múltiple y de identificación de errores

\section{Resumen}

INTRODUCCIÓN. Este estudio busca discernir el impacto de la ansiedad ante el desempeño de los exámenes de estudiantes de inglés.

MÉTODO. Cincuenta alumnas de niveles intermedio e intermedio-alto de inglés se dividieron en dos grupos: opción múltiple (OM) e identificación de errores (IE), de acuerdo con sus calificaciones en los exámenes que recibieron en la fase de pretest. Después de esta etapa, se administró un cuestionario para evaluar el nivel de ansiedad que comportaron estas pruebas. Durante un período de veinte semanas, el grupo IE recibió clases diseñadas a partir de ejercicios sobre identificación de errores, mientras que al grupo OM se le ofrecieron clases que incluían preguntas de opción múltiple. Tras el tratamiento, se volvieron a aplicar los mismos exámenes y el cuestionario.

RESULTADOS I DISCUSIÓN. Los hallazgos mostraron que el nivel de ansiedad ante los exámenes es mayor en el grupo que recibió el formato de IE de la prueba de conocimiento de vocabulario. A través de este estudio se observó el papel positivo de la familiarización y el impacto negativo de la ansiedad debilitante. Los hallazgos del estudio actual se pueden transferir a otras pruebas de competencia de alto nivel.

\section{Palabras clave}

Evaluación; Identificación de errores; Ítems de opción múltiple; Ansiedad ante los exámenes; Conocimiento de vocabulario 


\section{Introduction}

Assessment is a controversial issue; according to Black and Wiliam (2003) it "is not a simple or innocent term" (p. 1); it casts a "long, dark shadow". Wiliam (1994) defined assessment as "a procedure for eliciting evidence that can assist in educational decision making" (p. 6). The purpose of the assessment and identity of the assessor should also be taken into account when defining assessment. According to Shepard (2000) an assessment that assists the learner in his process of learning is instructionally supportive. Thus, to have the desired positive effect, assessments should be made more informative, the social meaning of evaluation needs to be changed and the pervasive negative effects of testing should be addressed.

Producing good tests is a formidable task that requires "substantive knowledge and psychometric expertise" (Iliescu, 2017, p. 27). Good tests, according to Kaewmala (2012), reveal whether students are capable of applying their knowledge to their routine activities. More specifically, Carroll (1961) describes a good test as:

an experiment, in the sense that it must eliminate or at least keep constant all extraneous sources of variation. We want our tests to reflect only the particular kind of variation in knowledge or skill that we are interested in at the moment. (p. 319)

Fulcher and Davidson (2007) concluded that standardized tests have more positive than negative effects. However, an ever-growing emphasis on testing has led to an increased level of test anxiety among students (Zeidner \& Matthews, 2010).

When determining test anxiety various sources of anxiety such as differences in testing conditions, fatigue as well as type of anxiety should be taken into account as they might have an impact on learners' test performance, and might vary over time (Bachman, 1990). Test anxiety is a feeling somebody may experience on an occasion where good performance is essential or when there is pressure to perform well, and can be defined as a "psychological condition" that causes extreme distress and tension for test takers. In other words, it is a mixture of symptoms and reactions that interfere with the ability to perform well in tests. The levels of test anxiety can vary among language learners, as can the type of anxiety namely debilitating and facilitating anxiety. While the former type is "an anxiety felt by a person that interferes with his performance, such as being psyched out or not in the zone" (Nugent, 2013, para. 1) and can be "so extreme that it gets in the way of successful performance" (Wiseman \& Hunt, 2013, p. 83), the latter, on the other hand, can leverage language learners' ego strength.

The level of anxiety might vary between people but have the same result of impeding learning and interfering in test performance (Cherry, 2020). Test anxiety and test performance are directly correlated (Birjandi \& Alemi, 2010; Hembree, 1988; Zatz \& Chassin, 1985). In other words, the higher the test anxiety the poorer the student's results. Students might experience test anxiety before, during and after the test (Schnell et al., 2011). They can show calmness while reacting with strong anxiety to being tested (Zeidner \& Matthews, 2010).

Of various sources of test anxiety, parents and teachers' expectations of success can agitate students and make them deliver a poorer performance (Erözkan et al., 2017). The sources of test anxiety might also be unclear or inaccurate instructions and inadequate time allocation, which in turn adversely affect test performance (Madsen, 1983). In addition, test anxiety might correlate with learners' performance and their understanding of the task (Fulcher \& Davidson, 2007). 
Learners' responses to a test and their level of anxiety go hand in hand with the test format. Resnick and Klopfer (1989) stated that "fill in the bubble or multiple-choice tests do not represent recent improvements in our understanding of what and how students learn" (p. 2). Furthermore, the above-mentioned types of assessments are neither useful for gathering information nor adequately precise for evaluating students' learning (Aschbacher, 1991; Brown \& Hudson, 1998; Genesee, 2001; Huerta-Macias, 1995; O'Malley \& Pierce, 1996). Assessment must complement the complex nature of knowledge and should take place in a form that makes the process of knowledge construction observable to some extent.

To investigate learners' test anxiety, the most practical and functional test types should be selected and administered. The multiple-choice item is the ultimate archetype (Fulcher, 2013). Multiple-choice tests are fast, easy and can be scored objectively (Bailey, 1990), and are more scorable than a response to an openended writing prompt (Fulcher, 2013). Error identification items that aim to measure language learners' knowledge of vocabulary and indirectly test their reading comprehension skill consist of a complete sentence with four vocabulary items underlined, of which one is inappropriate in terms of meaning. This test was designed and developed by the researcher. The error identification format is considered easy to construct, as well as being efficient (Nihae \& Chiramanee, 2014). Nonetheless, the error identification method can have negative effects because many students tend to regard every sentence as having an error (Heaton, 1990) and they have to read and consider each response option carefully and draw on various kinds of grammatical knowledge to respond correctly (Gergely, 2008).

\subsection{Significance and purpose of the study}

English language teaching and learning in the Iranian context have gained considerable attention over the years (Hayati \& Mashhadi, 2010), and the upward trend in improving ELT has led to an increase in the number of private English language institutes.

In Iran, the main paradigm in English language testing has been narrowed down to a set of discretepoint, often multiple choice, written test items - see Farhadi and Keramati (2009) for an overview and thus investigating the level of anxiety these common tests can bring about among Iranian learners is important. The impact of test formats, especially vocabulary testing, on students' performances has not yet been investigated. Couch et al. (1983) revealed that a relationship does exist between the type of test anxiety and language learners' gender. However, the current study was limited to studying the level of test anxiety among one gender, namely females.

In summary, the purpose of this study was to determine the effect of test anxiety produced by the use of multiple-choice test and error identification tests for testing vocabulary knowledge on Iranian English language learners' performance.

\section{Research methodology}

\subsection{Participants}

Fifty female English language learners were randomly selected as the participants of the current study from Shokouh language institute, one of the main private institutions in Iran. Students were aged 16 to 24 . They were studying at the intermediate and upper-intermediate level of English language. 


\subsection{Instruments}

\subsubsection{Vocabulary Knowledge Test (pre-test and post-test)}

A vocabulary test of 60 questions was designed using the book Oxford Word Skills by Ruth Gairns and Stuart Redman (2008) to test students' vocabulary knowledge. This test consisted of 30 multiple-choice items and 30 error identification items, which require students to choose mistakenly placed words. This test took approximately 30 minutes to complete. The validity and reliability of this test was proved by a board of university professors at University of Guilan.

The test was administered twice, once at the beginning of the course as the pre-treatment test to identify students' knowledge of vocabulary items and then at the end of term as the post-treatment test in order to discern the effect of the treatment. According to the results of the pre-treatment test, students were assigned to two groups of 25 participants each.

\subsubsection{Lesson Plans}

Forty lesson plans were designed to develop students' knowledge of vocabulary including twenty plans using multiple-choice exercises and twenty plans offering error identification activities. The former was given to the group that will hereafter be called the multiple-choice group (MC group) while the other group, referred to as the error identification group (EI group), received the latter. Although the lesson plans were based on different test formats, they aimed at building up the same vocabulary families, i.e. learning, people, the world around us, daily life, getting things done, and describing things. Over 20 sessions, each group received 30 hours of instruction.

\subsubsection{Test Anxiety Questionnaire}

There are several instruments that can be used to determine test anxiety in learners, of which The Foreign Language Classroom Anxiety Scale (FLCAS), developed by Horwitz et al. (1986), is a good practical example. However, to fully assess the participants in the current study and observe their level of anxiety, a 5-point Likert scale type questionnaire was designed. The model applied by Scott (1986) and Cassady and Johnson (2002) was modified to suit our context. This questionnaire consisted of 20 items related to how one generally feels when taking the two test formats. The items in this questionnaire ranged from "Strongly Disagree" to "Strongly agree" with values 1-5 assigned to them respectively. It is worth noting that the items were translated into Farsi in order to avoid any possible misunderstanding.

\subsection{Procedure}

The vocabulary test was administered to all 50 students in the first week, in order to measure their vocabulary knowledge and assign them to two groups. Then the anxiety questionnaire was given to them to identify their attitudes towards two different test formats: multiple-choice and error identification tests. Through exposure of the El group to error identification and the MC group to multiple-choice exercises, they were expected to build up their knowledge of vocabulary items. 
At the end of their course, the same test that was administered in the pre-teaching phase was once more given to both groups to investigate their progress in vocabulary knowledge. The anxiety questionnaire was then administered a second time, using the same procedure as in the pre-teaching phase.

According to Dörnyei (2012), in order to examine the relationship between two variables we should perform a correlation analysis, since this allows us to look at two variables and evaluate the strength and direction of their relationship or association with each other. To calculate the correlation between two variables, the Pearson product moment correlation is used. According to Dörnyei (2012), this is "the standard type, computed between two continuous variables. When we talk about 'correlation' in general, this is what we usually mean" (p. 224). The Pearson correlation coefficient, $r$, can take a range of values from +1 to -1 . A value of 0 indicates that there is no association between the two variables. A value greater than 0 indicates a positive association; that is, as the value of one variable increases or decreases, so does the value of the other variable. A value less than 0 indicates a negative association. That is, as the value of one variable increases, the value of the other variable decreases. According to Mackey and Gass (2015), the correlation coefficient gives information about the extent to which there is a linear relationship between the variables. The results of the current study were thus analyzed using Pearson product moment correlation to investigate whether a relationship of any type exists between the study variables.

\section{Results and discussion}

The levels of anxiety produced in both groups are tabulated in Table 1.

Table 1

Test anxiety produced by multiple-choice (MC) and error identification (EI) formats in two study groups

\begin{tabular}{|c|c|c|c|c|c|c|c|c|}
\hline \multirow[b]{3}{*}{ Group } & \multirow{3}{*}{$\begin{array}{l}\text { Vocabulary } \\
\text { knowledge test }\end{array}$} & \multicolumn{4}{|c|}{ Level of test anxiety } & \multirow[b]{3}{*}{ Decrease } & \multicolumn{2}{|c|}{ Paired-sample t-test } \\
\hline & & $\begin{array}{l}\text { Befor } \\
\text { treat }\end{array}$ & $\begin{array}{l}\text { e } \\
\text { ment }\end{array}$ & $\begin{array}{l}\text { After } \\
\text { treat }\end{array}$ & ment & & & \\
\hline & & $\bar{x}$ & S.D. & $\bar{x}$ & S.D. & & t-value & 2-tail sig \\
\hline \multirow[t]{2}{*}{ MC group } & MC version & 3.12 & 0.29 & 2.53 & 0.11 & 0.59 & -1.611 & 0.175 \\
\hline & El version & 2.98 & 0.61 & 2.13 & 0.38 & 0.85 & -0.989 & 0.347 \\
\hline \multirow[t]{2}{*}{ El group } & MC version & 3.07 & 0.37 & 2.71 & 0.29 & 0.36 & -1.009 & 0.098 \\
\hline & El version & 3.21 & 0.52 & 3.01 & 0.34 & 0.20 & -1.059 & 0.164 \\
\hline
\end{tabular}

As shown in Table 1, the level of anxiety in the two groups was similar before teaching began, with a slightly higher level of anxiety in the El group. Regarding the consistency of the scores, the results at the end of the term, post-treatment, differed from those in the pre-treatment, with a significant reduction in anxiety for all tests. However, even the greatest reductions, in $M C$ group, were not statistically significant, 0.59 and 0.85 respectively for $\mathrm{MC}$ tests and El tests.

Although the $M C$ group was less anxious after the 20-week treatment, their counterpart, the El group, did not experience a lower level of anxiety compared to the pre-treatment period. In this regard, it was shown that practice has a positive impact on learners' level of anxiety. In other words, the more they practiced, the lower their level of anxiety. This familiarization with the vocabulary items helped the students be less 
anxious after the second test. Cassady and Johnson (2002) also proved that test anxiety affects test performance, and Young (1999) found that familiarization with the topic can help learners reduce their level of anxiety; however, the findings of the current study add to the literature by showing that this reduction can be significant in particular areas in certain contexts. Accordingly, practitioners would expect lower levels of anxiety as the learners become more familiar with the topic. However, they still exhibit more anxiety when taking error identification tests rather than multiple-choice items, which might itself be a result of students' familiarity with this type of question during their studies.

Another important part of the current research is the relationship between test anxiety and test performance. In order to determine whether a significant relationship exists between students' performance and the level of test anxiety, their scores in both types of vocabulary knowledge test (multiplechoice and error identification) and their level of anxiety were analyzed using the Product Moment Correlation Coefficient Test. Table 2 shows the relationship between students' scores and their level of anxiety after the tests.

\section{Table 2}

Relationship between test scores and test anxiety

\begin{tabular}{llll}
\hline Group & Scores on vocabulary test & $\begin{array}{l}\text { Level of test anxiety } \\
\text { Before treatment } \\
\text { Pearson } r\end{array}$ & $\begin{array}{l}\text { After treatment } \\
\text { Pearson } r\end{array}$ \\
\hline MC group & MC format & 0.121 & 0.011 \\
& El format & $-0.612^{*}$ & -0.235 \\
\multirow{2}{*}{ El group } & MC format & & -0.183 \\
& El format & 0.281 & -0.074 \\
\hline
\end{tabular}

As shown in Table 2, the correlations of the scores of students' performance in the El group before receiving treatment were significant. The correlation between students' scores in the error identification test and their level of anxiety was significant in both the MC and El groups (-0.612 and -0.803 respectively), indicating a strong negative correlation between test performance and level of anxiety. In other words, the higher the students' performance in the error identification tests, the lower their level of anxiety. This was not the case for the multiple-choice format of the vocabulary test, which could be due to the students' familiarity with the multiple-choice format. Trifoni and Shahini (2011) also found a correlation between test performance and test anxiety for the error identification format of vocabulary test.

\section{Conclusion}

This study sought to establish a relationship between performance in different testing formats of vocabulary knowledge, namely multiple-choice format and error identification format, and the level of anxiety caused by these tests. To this end, tests were administered to 50 English language learners before and after 30 hours of instruction in error identification for the El group and multiple choice test format for the MC group, during which they were provided with materials to learn English vocabulary items.

The findings support previous studies that demonstrated a negative relationship between test anxiety and language learners' performance (e.g. Chapell et al., 2005; Hancock, 2001; Hembree, 1988), meaning that as test anxiety level increases, students' performance decreases and vice versa. 
The current study had two significant findings. The first was that, in vocabulary knowledge tests, the level of anxiety that the error identification format brought about in the learners was appreciably higher than that brought about by the multiple choice format. This could be due to the students' greater familiarity with the multiple choice format.

The results also indicated that the more anxiety a vocabulary test produces the poorer performance a female English language learner will deliver. This is also transferrable to other tests including standardized proficiency tests such as the International English Language Testing System (IELTS) and Test of English as a Foreign Language (TOEFL). Through these tests, students can experience both error identification and multiple choice test formats, but with less emphasis on the former. The correct word choice, which is a major concern for candidates in these tests, can be addressed through teaching programs that offer error identification tests. However, more thorough investigations of test anxiety in these contexts should be addressed in future studies.

Universities and institutions focus on determining learning accomplishment using tests such as multiplechoice, essays, and short-answer tests. Moreover, because there are institutions that require students to achieve particular levels and scores in examinations such as IELTS or TOEFL, standardized tests are of utmost importance. However, a shift towards the administration of alternative assessment techniques such as portfolios, interviews, replacing tests with summaries, and take home exams could bring about more favorable results and reduce students' anxiety.

These findings of the current study will help English language practitioners and evaluators to adjust their method of teaching to the assessment method and to focus more on students' familiarization with test formats in order to improve performance. Modified test formats can lead to lower test performance and thus teachers' should highlight these modified versions. Vocabulary knowledge is usually assessed using multiple choice tests, which sometimes require the learners to translate each item. However, the focus should be shifted towards the use of error identification tests, which require the students to have an understanding of different aspects of a single word, including semantics and pragmatics.

\section{References}

Aschbacher, P. R. (1991). Performance Assessment: State Activity, Interest and Concerns. Applied Measurement in Education, 4(4), 275-288. https://doi.org/10.1207/s15324818ame0404_2

Bachman, L. F. (1990). Fundamental considerations in language testing. Oxford University Press.

Bailey, K. M. (1990). The use of diary studies in teacher education programs. In J. C. Richards \& D. Nunan (eds.), Second language teacher education (pp. 215-226). Cambridge University Press. https://files.eric.ed.gov/fulltext/ED367166.pdf

Birjandi, P., \& Alemi, M. (2010). The Impact of Test Anxiety on Test performance among Iranian EFL Learners. BRAIN Broad Research in Artificial Intelligence and Neuroscience, 1(4), 44-58. https://www.edusoft.ro/brain/index.php/brain/article/view/131/260

Black, P., \& Wiliam, D. (2003). 'In praise of educational research': Formative assessment. British educational research journal, 29(5), 623-637. https://doi.org/10.1080/0141192032000133721 
Brown, J. D., \& Hudson, T. (1998). The alternatives in language assessment. TESOL quarterly, 32(4), 653675. https://doi.org/10.2307/3587999

Carroll, J. B. (1961). Fundamental considerations in testing for English language proficiency of foreign students. Reprinted in H. B. Allen and R. N. Campbell (eds.) (1965), Teaching English as a Second Language: A Book of Readings (pp. 313-330). McGraw Hill.

Cassady, J. C., \& Johnson, R. E. (2002). Cognitive test anxiety and academic performance. Contemporary educational psychology, 27(2), 270-295. https://doi.org/10.1006/ceps.2001.1094

Chapell, M. S., Blanding, Z. B., Silverstein, M. E., Takahashi, M., Newman, B., Gubi, A., \& McCann, N. (2005). Test Anxiety and Academic Performance in Undergraduate and Graduate Students. Journal of Education Psychology, 97(2), 268-274. https://doi.org/10.1037/0022-0663.97.2.268

Cherry, K. (2020, March 25). Test Anxiety Symptoms, Causes, and Treatments. Verywell Mind. https://www.verywellmind.com/what-is-test-anxiety-2795368

Couch, J. V., Garber, T. B., \& Turner, W. E. (1983). Facilitating and debilitating test anxiety and academic achievement. The Psychological Record, 33(2), 237-244. https://doi.org/10.1007/BF03394841

Dörnyei, Z. (2012). Research methods in applied linguistics. Oxford Applied Linguistics.

Erözkan, A., Doğan, U., \& Adıgüzel, A. (2017). Sources of test anxiety: a qualitative approach. Journal of Education and Practice, 8(27), 85-100.

Farhadi, H., \& Keramati, H. (2009). Language assessment policy in Iran. Annual Review of Applied Linguistics, 29, 132-141.

Fulcher, G. (2013). Practical language testing. Routledge.

Fulcher, G., \& Davidson, F. (2007). Language testing and assessment. Routledge.

Gairns, R., \& Redman, S. (2008). Oxford word skills: Intermediate. Oxford University Press.

Genesee, F. (2001). Bilingual first language acquisition: Exploring the limits of the language faculty. Annual Review of Applied Linguistics, 21, 153-168. https://doi.org/10.1017/S0267190501000095

Gergely, G. (2008). Learning 'about' versus learning 'from' other minds: Natural pedagogy and its implications. In P. Carruthers, S. Laurence \& S. Stich (eds.), The Innate Mind: Foundations and the Future (pp. 170-199). Oxford University Press.

https://doi.org/10.1093/acprof:oso/9780195332834.003.0009

Hancock, D. R. (2001). Effects of test anxiety and evaluative threat on students' achievement and motivation. The Journal of Educational Research, 94(5), 284-290. https://doi.org/10.1080/00220670109598764

Hayati, M., \& Mashhadi, A. (2010). Language planning and language-in-education policy in Iran. Language Problems and Language Planning, 34(1), 24-42. https://doi.org/10.1075/Iplp.34.1.02hay

Heaton, J. B. (1988). Writing English Language Test (New Edition). Longman. 
Hembree, R. (1988). Correlates, causes, effects, and treatment of test anxiety. Review of educational research, 58(1), 47-77. https://doi.org/10.3102/00346543058001047

Horwitz, E. K., Horwitz, M. B., \& Cope, J. (1986). Foreign Language Clasroom Anxiety. The Modern Language Journal, 70(2), 125-132. https://doi.org/10.1111/j.1540-4781.1986.tb05256.x

Huerta-Macias, A. (1995). Alternative assessment: Responses to commonly asked questions. TESOL Journal, 5, 8-27. https://www.jstor.org/stable/3587999

Iliescu, D. (2017). Adapting tests in linguistic and cultural situations. Cambridge University Press.

Kaewmala. (2012). The education failure - part 2: Test score, standards and accountability [Online Post]. Prachatai English. https://prachatai.com/english/node/3080

Mackey, A., \& Gass, S. M. (2015). Second language research: Methodology and design. Routledge.

Madsen, H. S. (1983). Techniques in Testing. Oxford University Press.

McNamara, T., \& Roever, C. (2006). Language testing: The social dimension (Vol. 1). John Wiley \& Sons.

Nihae, N. I., \& Chiramanee, T. (2014). Multiple-choice and Error Recognition Tests: Effects of Test Anxiety on Test Performance. International Journal of English Language Education, 2(2), 78-88. https://doi.org/10.5296/ijele.v2i2.5854

Nugent, P. M. S. (2013). Debilitative anxiety. PsychologyDictionary.org. https://psychologydictionary.org/debilitative-anxiety/

O'Malley, J. M., \& Pierce, L. V. (1996). Authentic assessment for English language learners: Practical approaches for teachers. Addison-Wesley Publishing Company.

Resnick, L. B., \& Klopfer, L. E. (1989). Toward the Thinking Curriculum: Current Cognitive Research. 1989 $A S C D$ Yearbook. Association for Supervision and Curriculum Development.

Schnell, K., Tibubos, A., Rohrmann, S., Schienle, A., \& Hodapp, V. (2011). Test Anxiety in High-school students: Self-reports and Student-teacher agreement. In P. Buchwald, K. A. Moore \& T. Ringeisen (eds.), Stress and anxiety: application to education and health (pp. 45-54). Logos Verlag Berlin $\mathrm{GmbH}$.

Scott, M. L. (1986). Student affective reactions to oral language tests. Language Testing, 3(1), 99-118. https://doi.org/10.1177/026553228600300105

Shepard, L. A. (2000). The role of assessment in a learning culture. Educational researcher, 29(7), 4-14. https://doi.org/10.3102/0013189X029007004

Trifoni, A., \& Shahini, M. (2011). How does exam anxiety affect the performance of university students? Mediterranean Journal of Social Sciences, 2(2), 93-100. https://www.mcser.org/images/stories/2_journal/mjssmay2011/9.pdf 
Wiliam, D. (1994). Towards a philosophy for educational assessment [Paper presentation]. British Educational Research Association's $20^{\text {th }}$ annual conference, Oxford.

http://www.dylanwiliam.org/Dylan_Wiliams_website/Papers_files/BERA\%2094\%20paper.doc

Wiseman, D. G., \& Hunt, G. H. (2013). Best practice in motivation and management in the classroom. Charles C Thomas Publisher.

Young, D. J. (1999). Affect in foreign language and second language learning. McGraw-Hill.

Zatz, S., \& Chassin, L. (1985). Cognitions of test-anxious children under naturalistic test-taking conditions. Journal of Consulting and Clinical Psychology, 53(3), 393-401. https://doi.org/10.1037/0022006X.53.3.393

Zeidner, M., \& Matthews, G. (2010). Anxiety 101. Springer Publishing Company. 